\title{
PREEKLAMSIA DAN BAYI BERAT LAHIR RENDAH (BBLR) DI RSU ANUTAPURA PALU
}

\section{Preeclamsia and Low Birth Weight (LBW) In Anutapura Palu General Hospital}

\author{
Lisnawati $^{1}$, Nindy Nadyar Humairah ${ }^{2}$, Arie Maineny ${ }^{3}$ \\ 1,2,3 Poltekkes Kemenkes Palu \\ (kialisnawati@yahoo.com, 085242335590)
}

\begin{abstract}
ABSTRAK
Preeklampsia didefinisikan sebagai perkembangan hipertensi dan proteinuria setelah 20 minggu kehamilan. Tujuan penelitian untuk mengetahui hubungan preeklampsia dengan BBLR di RSU Anutapura Palu. Penelitian kasus-kontrol. Populasi sebanyak 186 bayi dengan sampel BBLR sebanyak 93 bayi, matching pada usia kehamilan 37, 38, 39, dan 40 minggu. Hasil penelitian menunjukkan bahwa dari Ibu yang mengalami preeklamsia melahirkan bayi BBLR 16 orang (64\%) dan tidak BBLR 9 bayi (36\%). Sedangkan ibu yang tidak mengalami preeklamsia melahirkan bayi BBLR 77 bayi $(47,8 \%)$ dan tidak BBLR 84 bayi (52,2\%). Rerata BBL pada ibu preeklamsia 2232,00gr sedangkan pada ibu yang tidak preeklampsia 2363,04gr. Hasil uji kai kuadrat p-value $=0,197(0,197>0,05)$ Disimpulkan meskipun prevalensi BBLR tinggi pada ibu yang mengalami preeklamsia namun tidak ada pengaruh yang signifikan antara preeklamsia terhadap kejadian bayi berat badan lahir rendah. Disarankan agar dilakukan analisis lebih lanjut dari faktor maternal lainnya terhadap kejadian BBLR di RSU Anutapura Palu.
\end{abstract}

Kata kunci : Preeklamsia dan BBLR

ABSTRACT

Preeclampsia is defined as the development of hypertension and proteinuria after 20 weeks of pregnancy. This research aims to determine the relationship between preeclampsia and LBW in Anutapura Hospital Palu. This research is a case-control research. The population was 186 infants and 93 infants LBW as samples, matching at 37, 38, 39, and 40 weeks gestation. The results showed that preeclampsia mothers gave birth to $16 \mathrm{LBW}$ babies (64\%) and 9 non LBW babies (36\%). While non preeclampsia mothers gave birth to $77 \mathrm{LBW}$ babies (47.8\%) and 84 non LBW babies (52.2\%). The mean BBL in preeclampsia mothers was 2232,00gr, whereas for non preeclampsia mothers was $2363,04 \mathrm{gr}$. Based on the results of the chi-square test $p$-value $=0.197$ (0.197> 0.05). As conclusion, despite the prevalence of high $L B W$ in preeclampsia mothers, there is no significant effect between preeclampsia and $L B W$ babies. It is recommended that further analysis of other maternal factors be carried out for the incidence of LBW in Anutapura Hospital Palu.

Keywords: Preeclampsia and Low Birth Weight 


\section{PENDAHULUAN}

Preeklampsia didefinisikan sebagai perkembangan hipertensi dan proteinuria yang terjadi setelah 20 minggu kehamilan $^{(1)}$. meliputi hingga $8 \%$ dari semua kehamilan di seluruh dunia pemicu angka morbiditas dan mortalitas di antara ibu dan bayi ${ }^{(2)}$. Preeklampsia adalah penyebab utama prematuritas dan hambatan pertumbuhan janin $^{(3)}$. Tingkat kematian bayi yang lahir dari ibu dengan Preeklampsia lebih tinggi dari pada bayi yang lahir dari ibu yang sehat ${ }^{(4)}$. Preeklamsia juga merupakan penyebab utama kedua dalam penerimaan unit perawatan intensif terkait kehamilan setelah perdarahan obstetrik $^{(5)}$. Selain itu, preeklamsia terkait dengan meningkatnya risiko penyakit kardiovaskular yang akan datang ${ }^{(6)}$. Indeks Massa tubuh dan kenaikan berat badan pra kehamilan dapat meningkatkan tingkat stres oksidatif, merangsang respons inflamasi sistemik, dan mempercepat kerusakan sel endotel pembuluh darah, yang mengakibatkan preeklampsia $^{(7)}$.

Prevalensi kasus preeklampsia/eklampsia di Indonesia sebesar 3,9\%, sebanyak 64,4\% ibu berumur 20-30 tahun, 69,5\% memiliki status paritas primigravida, frekuensi kehamilan kali $<4$ sebesar $76,3 \%{ }^{(8)}$. Analisis data 2011-2012 rekam medik di RSUD Undata Palu tahun dengan besar sampel 184 bayi menunjukkan hubungan yang bermakna antara preeklampsia dengan kejadian bayi BBLR $(\mathrm{p}=0,003)$. Preeklampsia merupakan faktor risiko BBLR dengan $\mathrm{OR}=2.48(9)$. Penelitian di Wangaya Bali, menunjukkan bahwa ada hubungan preeklampsia dengan BBLR. Ibu dengan preeklampsia empat kali lebih berisiko melahirkan bayi dengan BBLR ${ }^{(10)}$. Data RSU Anutapura Palu tahun 2016 mencatat kejadian preeklamsia sebanyak 43 kasus sedangkan BBLR sebanyak 117 kasus dan tahun 2017 kejadian preeklamsia sebanyak 104 kasus sedangkan BBLR sebanyak 93 kasus. Tujuan penelitian untuk mengetahui hubungan preeklampsia dengan BBLR di RSU Anutapura Palu.

\section{METODE PENELITIAN}

Pelaksanaan penelitian pada tanggal 18 Juli sampai dengan 3 Agustus 2018 di Ruangan Rekam Medik Rumah Sakit Umum Anutapura Palu. Jenis penelitian ini adalah penelitian kasus-kontrol. Populasi teliti adalah data rekam medis RSU Anutapura Palu.

Identifikasi dilakukan pada kelompok kasus dan pada kelompok kontrol, kemudian secara retrospektif diteliti ada tidaknya pengaruh preeklamsia dengan kejadian BBLR di RSU Anutapura Palu. Defenisi operasional dalam penelitian ini yaitu; preeklampsia adalah diagnosa pada ibu hamil dengan tekanan darah sistolik $\geq 140$ dan diastolik $\geq 90 \mathrm{mmHg}$, proteinuria $\geq+1$, edema, serta umur kehamilan 37-40 minggu yang melahirkan bayi BBLR dan tidak BBLR. Tidak preeklamsia jika tekanan darah sitolik $<140 \mathrm{mmHg}$ dan diastolik $<90 \mathrm{mmHg}$, proteinuria (-). Preeklamsia jika tekanan darah sitolik $\geq 140 \mathrm{mmHg}$ dan diastolik $\geq 90 \mathrm{mmHg}$, proteinuria (+).

Berat Badan Lahir Rendah (BBLR) adalah Berat badan bayi pada saat lahir $<2500$ gram dengan usia saat dilahirkan $37-40$ 
minggu. Tidak BBLR jika berat lahir bayi $\geq$ 2500 gram. BBLR jika berat lahir $<2500$ gram. Data utama yang digunakan dalam penelitian ini menggunakan data sekunder yang diperoleh dari buku rekam medik RSU Anutapura Palu periode tahun 2017. Sampel kasus dan sampel kontrol yang sesuai dengan tanpa matching yaitu umur kehamilan 37-40 minggu dan mengambil data pada buku pengkajian pasien form MR.6c dan lampiran laboratorium. Adapun data penunjang berupa data sekunder yang diperoleh dari laporan Dinas Kesehatan Propinsi Sulawesi Tengah tahun 2016-2017, laporan Dinas Kesehatan Kota Palu tahun 2016-2017, buku status pasien ruang Pingguin RSU Anutapura Palu periode 2016-2017.

\section{HASIL}

Berdasarkan tabel 1 menunjukkan bahwa karakteristik umur kehamilan lebih banyak pada umur kehamilan 37 minggu yaitu 32,3\% bayi, sedangkan terendah pada umur kehamilan 40 minggu yaitu $16,1 \%$ bayi. Berdasarkan tabel 2 menunjukkan bahwa ibu yang tidak preeklamsia paling banyak yaitu 161 orang $(86,6 \%)$, sedangkan yang paling sedikit ibu yang preeklamsia yaitu 25 orang $(13,4 \%)$.

Tabel 1. Karakteristik Umur Kehamilan di Rumah Sakit Umum Anutapura Palu

\begin{tabular}{ccc}
\hline Umur Kehamilan & f & \% \\
\hline 37 minggu & 60 & 32,3 \\
38 minggu & 50 & 26,9 \\
39 minggu & 46 & 24,7 \\
40 minggu & 30 & 16,1 \\
\hline Total & 186 & 100 \\
\hline
\end{tabular}

Sumber : Data Sekunder, 2018

Tabel 2. Frekuensi Preeklamsia dan BBLR di RSU Anutapura Palu

\begin{tabular}{|c|c|c|}
\hline Variabel & $\mathbf{f}$ & $\%$ \\
\hline \multicolumn{3}{|l|}{ Preeklamsia } \\
\hline Ya & 161 & 86,6 \\
\hline Tidak & 25 & 13,4 \\
\hline \multicolumn{3}{|l|}{ BBLR } \\
\hline Ya & 93 & 50 \\
\hline Tidak & 93 & 50 \\
\hline Total & 186 & 100 \\
\hline
\end{tabular}

Sumber : Data Sekunder, 2018

Tabel 3 menunjukkan bahwa dari Ibu yang mengalami preeklamsia melahirkan bayi BBLR 16 orang (64\%) dan tidak BBLR 9 bayi (36\%). Sedangkan ibu yang tidak mengalami preeklamsia melahirkan bayi BBLR 77 bayi $(47,8 \%)$ dan tidak BBLR 84 bayi $(52,2 \%)$.

Tabel 3. Tabulasi Silang Kejadian Preeklampsia dengan BBLR di Rumah Sakit Umum Anutapura Palu

\begin{tabular}{|c|c|c|c|c|c|c|c|}
\hline \multirow{3}{*}{ Preeklamsia } & \multicolumn{4}{|c|}{ Kejadian BBLR } & \multirow{3}{*}{$\frac{\text { Total }}{\mathbf{N}}$} & \multirow{3}{*}{$\begin{array}{c}\text { (OR) } \\
\text { CI=95\% }\end{array}$} & \multirow{3}{*}{ p value } \\
\hline & \multicolumn{2}{|c|}{ Tidak BBLR } & \multicolumn{2}{|c|}{ BBLR } & & & \\
\hline & f & $\%$ & $\mathbf{f}$ & $\%$ & & & \\
\hline Tidak Preeklamsia & 84 & 52,2 & 77 & 47,8 & 161 & & \\
\hline Preeklamsia & 9 & 36 & 16 & 64 & 25 & $\begin{array}{c}1,939 \\
(0.810-4644)\end{array}$ & 0,197 \\
\hline Total & 93 & 50 & 93 & 50 & 186 & & \\
\hline
\end{tabular}

Sumber : Data Sekunder, 2018

Berdasarkan hasil uji kai kuadrat dengan tingkat kesalahan 5\% diperoleh pvalue $=0,197$ $(0,197>0,05)$ dengan tingkat kepercayaan (CI) $95 \%$ nilai Odds Ratio (OR)=1,939 dengan interval kepercayaan (IK) $95 \% \quad 0,810-4,644$ artinya Ha ditolak dan Ho diterima dengan interpretasi tidak ada pengaruh preeklamsia dengan kejadian bayi BBLR. Berdasarkan hasil analisis OR yaitu ibu yang mengalami 
preeklamsia beresiko 1,9 kali lebih besar melahirkan BBLR dibandingkan ibu yang tidak preeklamsia

\section{PEMBAHASAN}

Berdasarkan hasil penelitian karakteristik umur kehamilan lebih banyak pada umur kehamilan 37 minggu yaitu 30 bayi, sedangkan terendah pada umur kehamilan 40 minggu yaitu 15 bayi. Asumsi peneliti menyatakan bahwa ibu yang melahirkan pada usia kehamilan kurang bulan dapat menyebabkan pertumbuhan janin terhambat sehingga bayi yang dilahirkan akan mempunyai BBLR.

Bedasarkan hasil uji statistik menunjukkan bahwa Ibu yang mengalami preeklamsia melahirkan bayi BBLR 16 orang (64\%) dan tidak BBLR 9 bayi (36\%). Sedangkan ibu yang tidak mengalami preeklamsia melahirkan bayi BBLR 77 bayi $(47,8 \%)$ dan tidak BBLR 84 bayi $(52,2 \%)$. Berdasarkan hasil uji kai kuadrat diperoleh pvalue $=0,197$ dan nilai Odds Ratio $(\mathrm{OR})=1,939$ artinya Ha ditolak dan Ho diterima dengan interpretasi tidak ada pengaruh preeklamsia dengan kejadian bayi BBLR. Berdasarkan hasil analisis OR yaitu ibu yang mengalami preeklamsia beresiko 1,9 kali lebih besar melahirkan BBLR dibandingkan ibu yang tidak preeklamsia. Hasil penelitian yang diperoleh tidak berbeda dengan hasil penelitian di Padang yang menyatakan bahwa terdapat perbedaan berat lahir bayi antara pasien preeklampsia berat/ eklampsia early dan late onset. Berat lahir bayi yang kecil untuk masa kehamilan (KMK) cenderung dilahirkan oleh pasien preeklampsia berat/ eklampsia earlyonset $(16,67 \%)$ sementara bayi dengan berat lahir sesuai untuk masa kehamilan (SMK) cenderung dilahirkan oleh pasien preeklampsia berat/ eklampsia lateonset $(92,65 \%)$. Namun tidak ada perbedaan berat lahir bayi antara pasien preeklampsia berat/eklampsia early dan late onset secara signifikan $\mathrm{p}=0,233^{(11)}$.

Penelitian di Poli KIA RSU Anutapura Palu menunjukkan bahwa tidak ada hubungan antara pemeriksaan antenatal care, riwayat hipertensi, paritas, dengan kejadian preeklampsia namun lebih berhubungan dengan antara umur, dan pengetahuan ${ }^{(12)}$.

Suatu penelitian yang bertujuan untuk untuk menyelidiki kinerja prediktif faktor pertumbuhan plasenta (PLGF) dan FMS-like kinase 1 (SFLT-1) sebagai penanda pada berat lahir bayi usia gestasi yang rendah (SGA), dalam kohort berbasis populasi yang besar menemukan bahwa Rasio SFLT-1/PLGF merupakan prediktor potensial SGA dalam skrining berbasis populasi, khususnya pada pasien yang menderita preeklampsia ${ }^{(13)}$.

Penelitian di China menunjukkan bahwa Indeks Massa Tubuh dan penambahan berat badan gestasional pra-kehamilan merupakan faktor risiko independen untuk preeklampsia dan bahwa risikonya dapat bervariasi berdasarkan subtipe preeklampsia ${ }^{(14)}$.

Penelitian di China yang bertujuan untuk menyelidiki apakah penanda biokimia serum ibu pada awal trimester ketiga dapat memprediksi preeklampsia dan berat lahir neonatal, menunjukkan bahwa Penanda individu Trigliserida, kolesterol total Low Density Lipoprotein, kolesterol high-density 
lipoprotein, LDL/HDL, asam urat, $\mathrm{Ca} 2+$, dan homosistein $79 \%$. Area di bawah kurva (AUC) UA adalah 0,70, yang merupakan yang tertinggi di antara delapan penanda ini, namun AUC dari model kombinasi delapan penanda $(0,85)$ memiliki indikasi diagnostik yang lebih baik. (3) Pada preeklampsia, tekanan darah sistolik/diastolik maksimum berkorelasi positif dengan serum asam urat $(r=0,212 / 0.205, p$ $<0,0001)$; dan berkorelasi negatif dengan kalsium total serum ( $\mathrm{r}=-0,193 /-0,196$, $\mathrm{p}=0,001)$. Berat lahir neonatal kelompok preeklampsia memiliki korelasi positif dengan kadar TG serum $(r=0,141, p=0,017)$ dan kadar kalsium total serum $(r=0,221, p<0,0001)$ dan korelasi negatif dengan tingkat asam urat $(\mathrm{r}=-$ 0,265, $\mathrm{p}<0,0001)$ dapat memprediksi preeklampsia. Pemantauan dan evaluasi bersama terhadap parameter ini dapat meningkatkan efisiensi skrining untuk prediksi PE dan pertumbuhan janin yang buruk sejak $\operatorname{dini}^{(15)}$.

Asumsi peneliti menyatakan bahwa ibu yang tidak mengalami preeklamsia umumnya melahirkan bayi yang tidak BBLR tetapi masih terdapat ibu dengan preeklamsia melahirkan bayi yang BBLR karena adanya faktor lain yaitu umur kehamilan karena pada bayi yang dilahirkan dengan umur kehamilan yang belum cukup bulan (aterm) masih terjadi proses pertumbuhan dan organ-organ janin belum lengkap sehingga bayi akan terjadi BBLR, dan juga karena faktor ekonomi keluarga. Faktor biologis, sosial, ekonomi, lingkungan, dan gaya hidup yang tidak memadai, baik sebelum atau selama kehamilan, dapat menyebabkan berat badan lahir rendah ${ }^{(16)}$.
Keluarga yang mampu memenuhi kebutuhan gizi ibu hamil akan mencegah kejadian ibu melahirkan bayi BBLR.

\section{KESIMPULAN DAN SARAN}

Ibu yang mengalami preeklamsia melahirkan bayi BBLR sebesar $64 \%$ dan tidak BBLR 36\%. Ibu yang tidak mengalami preeklamsia melahirkan bayi BBLR 47,8\% dan tidak BBLR 52,2\%. Rerata BBL pada ibu preeklamsia 2232,00gr sedangkan pada ibu yang tidak preeklampsia 2363,04gr. Berdasarkan hasil uji kai kuadrat p-value = $0,197 \quad(0,197>0,05) \quad$ Meskipun prevalensi BBLR tinggi pada ibu yang mengalami preeklamsia namun tidak ada pengaruh yang signifikan antara preeklamsia terhadap kejadian bayi berat badan lahir rendah. Disarankan agar dilakukan analisis lebih lanjut dari faktor maternal lainnya terhadap kejadian BBLR di RSU Anutapura Palu.

\section{DAFTAR PUSTAKA}

1. Hutcheon JA, Lisonkova S, Joseph KS. Epidemiology of pre-eclampsia and the other hypertensive disorders of pregnancy. Best Pract Res Clin Obstet Gynaecol [Internet]. 2011;25(4):391-403. Available from:

http://www.sciencedirect.com/science/articl e/pii/S1521693411000198

2. Roberts JM, Cooper DW. Pathogenesis and genetics of pre-eclampsia. Lancet [Internet]. 2001 Jan 6;357(9249):53-6. Available from: https://doi.org/10.1016/S01406736(00)03577-7

3. Redman CW, Sargent IL. Latest Advances in Understanding Preeclampsia. Science (80- ) [Internet]. 2005 Jun 10;308(5728):1592 LP - 1594. Available from: http://science.sciencemag.org/content/308/5 728/1592.abstract

4. Roberts JM, Pearson GD, Cutler JA, Lindheimer MD. Summary of the NHLBI Working Group on Research on Hypertension during Pregnancy. Hypertens 
Pregnancy. 2003;22(2):109-27.

5. Porreco RP, Barkey R. Peripartum intensive care. J Matern Neonatal Med [Internet]. 2010 Oct 1;23(10):1136-8. Available from: https://doi.org/10.3109/14767058.2010.490 890

6. Haugen M, Brantsæter AL, Winkvist A, Lissner L, Alexander J, Oftedal B, et al. Associations of pre-pregnancy body mass index and gestational weight gain with pregnancy outcome and postpartum weight retention: A prospective observational cohort study. BMC Pregnancy Childbirth. 2014;14(1):1-11.

7. Ornaghi S, Tyurmorezova A, Algeri P, Giardini V, Ceruti P, Vertemati E, et al. Influencing factors for late-onset preeclampsia. J Matern Neonatal Med [Internet]. 2013 Sep 1;26(13):1299-302. Available from: https://doi.org/10.3109/14767058.2013.783 807

8. Djannah, Sitti N IS. Gambaran epidemiologi kejadian preeklampsia/ eklampsia RSU PKU Muhamadiyah Yogyakarta. 2009;(0274). Available from: http://ejournal.litbang.depkes.go.id/index.p hp/hsr/article/download/2782/1506http://jur nal.fk.unand.ac.id/index.php/jka/article/vie $\mathrm{w} / 591 / 479$

9. Mallisa B, Towidjojo VD. Hubungan antara Preeklampsia dengan Kejadian Bayi Berat Badan Lahir Rendah (BBLR) Di RSUD Undata Palu suatu Penelitian Case-Control. Med Tadulako J Ilm Kedokt. 2014;1(3):17.

10. Hartati NN, Surinati IDAK, Pradnyaningrum NNDV. Preeklampsia dengan Berat Badan Lahir Rendah (BBLR) pada ibu bersalin. J Gema Keperawatan. 2018;000:1-9.

11. Amelia R, Azmi S. Perbedaan Berat Lahir Bayi Pasien Preeklampsia Berat / Eklampsia Early dan Late Onset di RSUP Dr . M . Djamil Padang. J Kesehat Andalas. 2013;5(1):135-8.

12. Situmorang T, Damantalm Y, Januarista A, Sukri. Faktor-faktor yang berhubungan dengan kejadian Preeklampsia pada ibu Hamil di Poli KIA RSU Anutapura. J Kesehat Tadulako. 2016;2(1):34-44.

13. Bækgaard Thorsen, L. H., Bjørkholt Andersen, L., Birukov A, Lykkedegn S, Dechend R, Stener Jørgensen, J., \& Thybo Christesen H. Prediction of birth weight small for gestational age with and without preeclampsia by angiogenic markers: an Odense Child Cohort study. J Matern Neonatal Med [Internet]. 2018;1:1-8.
Available

from: http://www.embase.com/search/results?sub action=viewrecord\&from=export\&id=L624 036969\%0Ahttp://dx.doi.org/10.1080/1476 7058.2018.1519536

14. Shao Y, Qiu J, Huang H, Mao B, Dai W, He X, et al. Pre-pregnancy BMI, gestational weight gain and risk of preeclampsia: A birth cohort study in Lanzhou, China. BMC Pregnancy Childbirth. 2017;17(1):1-9.

15. Sun L-J, Xu G-F, Lv M, Zhou H, Huang HF, Luo Q. Predictive Value of Maternal Serum Biomarkers for Preeclampsia and Birth Weight: A Case-Control Study in Chinese Pregnant Women. J Women's Heal. 2018;27(12):1519-24.

16. Figueiredo ACMG, Gomes-Filho IS, Silva RB, Pereira PPS, Da Mata FAF, Lyrio AO, et al. Maternal anemia and low birth weight: A systematic review and metaanalysis. Nutrients. 2018;10(5):1-18. 